\title{
Phytoplankton biomass dynamics and environmental variables around the Rocas Atoll Biological Reserve, South Atlantic
}

\author{
Marina Cavalcanti Jales*, Fernando Antônio do Nascimento Feitosa, Maria Luise Koening, \\ Manuel de Jesus Flores Montes, Moacyr Cunha de Araújo Filho, Rodolfo Araújo da Silva
}

\author{
Universidade Federal de Pernambuco. \\ (Av. Arquitetura S/N, Departamento de Oceanografia, Cidade Universitária, Recife - Pernambuco, Brasil) \\ *Corresponding author: marinajales@hotmail.com \\ Financial Support: Bolsista FACEPE
}

\begin{abstract}
The Rocas Atoll Biological Reserve is located in the Atlantic Ocean, at $3^{\circ} 51^{\prime} \mathrm{S}$ and $33^{\circ} 49^{\prime} \mathrm{W}$. It lies 143 nautical miles from the City of Natal, Rio Grande do Norte (Brazil). The purpose of this study was to analyze the hydrology, water masses, currents and chlorophyll a content to determine the dynamics of phytoplankton biomass around the Rocas Atoll. Samples were collected in July 2010 in the area around the Atoll, using the Research Vessel Cruzeiro do Sul of the Brazilian Navy. Two transects were established according to the surface currents, one of which at the southeast of the Atoll (SE) and the other at norwest (NW). Three collection points were determined on each of these transects. Samples were collected at different depths (surface and DCM - Deep Chlorophyll Maximum) and different times (day and night). According to PCA (Principal Component Analysis), the nutrients analyzed, DIN (dissolved inorganic nitrogen), DIP (dissolved inorganic phosphorus) and silicate, were inversely correlated with temperature and dissolved oxygen. Most environmental variables showed a significant increase due to the turbulence on the Northwest transect. There was an increase in the concentration of chlorophyll $a$ and nutrients when the temperature and oxygen in the mixed layer was reduced due to the influence of the SACW (South Atlantic Central Water). Despite the increase observed in some variables such as nutrient salts and chlorophyll $a$, the temperature in the mixed layer attained a mean value of $23.23{ }^{\circ} \mathrm{C}$ due to the predominance of Tropical Water. The increase of the phytoplankton biomass on the NW transect was, therefore, caused by the "island effect" and not by upwelling.
\end{abstract}

Descriptors: Reef environment, Chlorophyll $a$, Hydrology, Surface current.

\section{RESUMO}

A Reserva Biológica do Atol das Rocas situa-se no Oceano Atlântico, a $3^{\circ} 51$ 'S e $33^{\circ} 49^{\prime}$ W, distante 143 milhas náuticas da cidade de Natal, estado do Rio Grande do Norte (Brasil). Este estudo teve como objetivo analisar a hidrologia, massas de água, correntes e o teor de clorofila $a$ para determinar a dinâmica da biomassa fitoplanctônica em torno do Atol das Rocas. As amostras foram coletadas em julho de 2010 na área em torno do atol, usando o navio Oceanográfico da Marinha do Brasil, Cruzeiro do Sul. Dois transectos foram estabelecidos de acordo com a corrente superficial, um transecto em direção sudeste (SE) e o outro, em direção noroeste (NO) do Atol das Rocas. Nestes transectos foram determinados três pontos de coleta para cada um. As amostras foram coletadas em diferentes profundidades (superfície e PMC - Profundidade Máxima de Clorofila) e diferentes períodos do dia (dia e noite). De acordo com a ACP (Análise de Componentes Principais), observou-se que os nutrientes analisados, NID (nitrogênio inorgânico dissolvido), PID (fósforo inorgânico dissolvido) e silicato, correlacionaram-se inversamente com a temperatura e oxigênio dissolvido. A maioria das variáveis ambientais apresentou aumento significativo em função da turbulência no transecto noroeste. Pode-se observar que houve aumento dos teores de clorofila $a$ e nutrientes, e redução da temperatura e oxigênio na camada de mistura em função da influência da ACAS (Água Central do Atlântico Sul). Apesar do aumento observado em algumas variáveis, como sais nutrientes e clorofila $a$, a temperatura na camada de mistura esteve com valor médio de $23,23{ }^{\circ} \mathrm{C}$, devido ao predomínio da Água Tropical. Portanto, o aumento de biomassa fitoplanctônica no transecto NW foi provocado pelo "efeito ilha" e não pela ressurgência.

Descritores: Ambiente recifal, Clorofila $a$, Hidrologia, Corrente superficial. 


\section{INTRODUCTION}

Tropical oceans, in general, can be considered "blue deserts", or areas of low productivity and biomass, but high planktonic diversity (LONGHURST; PAULY, 2007). However, the submarine relief with its mountains and islands, as well as local currents, can influence the hydrological processes and also the physical processes such as transport and mixing, which are reflected in the concentration of chlorophyll $a$ in surface water (SOUZA et al., 2013). According to LEITE et al. (2008), this increase in planktonic biomass around these areas, makes these islands and seamounts the main targets of ocean fisheries off northeastern Brazil.

According to MACÊDO et al. (2009), at low latitudes the temperature variation is not very great and it does not, therefore, cause any marked changes in the biological rhythms of organisms. The thermocline, which forms an ecological barrier, reduces nutrient turnover between deep and superficial layers, limiting primary production. The waters found beneath this "barrier" exhibit more stable physical and chemical variables and are deeper and colder. This is due to the fact that they do not suffer direct interference from environmental factors such as wind, rain, sunlight and evaporation. In tropical regions this thermocline is located at a depth of between 50 and $170 \mathrm{~m}$ (SOUZA et al., 2013).

While nutrients are limited to the surface layer, the vertical penetration of light is the limiting factor for primary productivity below the thermocline. Thus, only the strata near the thermocline are not limited by light and nutrients, favoring photosynthesis. This explains the existence of a characteristic Deep Chlorophyll Maximum (DCM), close to the base of the mixed layer (METZLER et al., 1997). CORDEIRO et al. (2013) reported that these mixing processes between the water masses above and below the thermocline may occur on a scale of dozens of meters.

Some studies suggest that the significant increase of plankton biomass and nutrient mixture near ocean islands is associated with the "island mass effect." This term refers to the effects of the turbulence which changes the dynamics of ocean circulation around these areas, causing moderately deep water, rich in nutrients, to rise into the photic zone (DOTY; OGURI, 1956). Some studies, such as those of GILMARTIN and REVELANTE (1974) in Hawaii; PALACIOS (2002) in Galapagos; MARTINEZ and MAAMAATUAIAHUTAPU (2004) in French Polynesia; MELO et al. (2012) in the Archipelago of São Pedro e
São Paulo, and LIRA et al. (2014) in Fernando de Noronha Archipelago, reported these occurrences and the ecological influence that the "island mass effect" can have.

However, despite the recognized ecological importance of the island ecosystem, studies on plankton in the Rocas Atoll are still scarce, and may be mentioned PINTO et al. (1997); FEITOSA and PASSAVANTE (2004); MAFALDA JÚNIOR et al. (2009); CHAVES et al. (2008); NOGUEIRA and SASSI (2011) and SOUZA et al. (2013). This demonstrates the need for further investigation into the dynamics of plankton and oceanographic variables around the Rocas Atoll in the South Atlantic Ocean.

The present study aims to analyze the hydrology, water masses, currents and chlorophyll $a$ content to determine the dynamics of the phytoplankton biomass around the Rocas Atoll Biological Reserve. The null hypothesis to be tested was: the chlorophyll $a$ content and the nutrients analyzed in the study area are very low, thus demonstrating an absence of upwelling, but a significant difference between the transects analyzed regarding the predominant surface current.

\section{MATERIAL AND METHODS}

The Rocas Atoll is located in the Atlantic Ocean, south of the equator, at $3^{\circ} 51^{\prime} \mathrm{S}$ and $33^{\circ} 49^{\prime} \mathrm{W}$. It lies 143 nautical miles from the city of Natal, Rio Grande do Norte, Brazil (GHERARDI; BOSENCE, 2001). It was formed on the flattened top of a volcano whose base lies at $4000 \mathrm{~m}$ depth on the seafloor (KIKUCHI; LEÃO, 1997; GHERARDI; BOSENCE, 2005).

According to MEDEIROS et al. (2009), the fracture process that led to the creation of the Fernando de Noronha Archipelago also created the Rocas Atoll and a series of banks found along the coast of Ceará and Rio Grande do Norte States.

The temperature may reach $42{ }^{\circ} \mathrm{C}$ in the tidal pools, with the surface salinity ranging between 35 and 39 (PINTO et al., 1997). The mesotide regime is semidiurnal, with a maximum variation of $2.7 \mathrm{~m}$, exposing the reef flat at low spring tide (GHERARDI; BOSENCE, 1999).

The climate is considered hot and tropical with a mean annual temperature of $26{ }^{\circ} \mathrm{C}$, with a maximum absolute temperature of $32{ }^{\circ} \mathrm{C}$ and a minimum of $18{ }^{\circ} \mathrm{C}$. The annual rainfall varies between 1250 and $1500 \mathrm{~mm}$, and the rainy season occurs between March and July. The most intense rainfall occurs in April while October is considered the driest month. There is a high relative humidity of $80 \%$ or 
more all year round (ANDRADE, 1960; IBAMA, 1989) apud SCHULZ-NETO (2004).

East and southeast winds are prevalent throughout the year, with an average frequency of $45 \%$. Between June and August, winter in the Southern Hemisphere, 35\% of winds come from the SE and 15\% from the E. During summer in the Southern Hemisphere, between December and April, the occurrence of SE winds is of about $20 \%$. The wind speed varies from 6 to $10 \mathrm{~m} / \mathrm{s}$, dominant throughout the year. During the winter, however, wind speeds between 11 and $15 \mathrm{~m} / \mathrm{s}$ are common. Speeds exceeding $20 \mathrm{~m} / \mathrm{s}$ are recorded more frequently during the summer months (KIKUCHI; LEÃO, 1997).

The water masses reported for the study area are as follows: Tropical Water (TW), South Atlantic Central Water (SACW), Antarctic Intermediate Water (AIW), North Atlantic Deep Water (NADW) and Antarctic Bottom Water (ABW) (MEDEIROS et al., 2009).

The Rocas Atoll Biological Reserve (ReBio) was established on June 5, 1979 and is comprised of the atoll itself and the surrounding waters as far out as the 1,000 $\mathrm{m}$ isobath. Prior to the creation of ReBio, the atoll was a target of intense fishing activity and extraction of coral and sand (MORAES et al., 2003). Currently the reserve is used strictly for scientific and educational activities.

The field work was conducted around the Rocas Atoll Biological Reserve in July 2010. Data were collected both day and night at each sampling point. The Research Vessel Cruzeiro do Sul (NH 38), belonging to the Brazilian Navy, was used for this.

Water-column profiling was undertaken at all the stations with a conductivity, temperature and depth system (CTD); in addition to these sensors, a fluorescence sensor was also connected to the CTD. Water samples were collected with $5 \mathrm{~L}$ Niskin bottles coupled to a rosette system at previously determined levels.

In the insular oceanic area, two transects were made with three sampling points on each (Figure 1): one SE (Southeast) and one NW (Northwest) transect, in relation to the prevailing surface current. The predominant direction of the currents from $0 \mathrm{~m}$ to $350 \mathrm{~m}$ was, therefore, determined, by means of an ADCP hull, before the sampling was begun in the study area.

The thermocline depth and DCM were used as references for the sampling. For these in situ measurements, a CTD coupled with a fluorometer was used. However, in shallow areas, the deepest sample occurred at $75 \%$ of the location depth.
The rainfall data for the month of July during the last 10 years were acquired through the meteorological station of Fernando de Noronha and provided by Pernambuco State Agency for Water and Climate (APAC).

Niskin bottles and a rosette coupled to CTD were used for the water samples taken for the analysis of dissolved oxygen, salinity and dissolved inorganic nutrients such as ammonia, nitrite, nitrate, phosphate and silicate.

While the water samples were still on board, the dissolved oxygen content was determined by the modified Winkler method described by STRICKLAND and PARSONS (1972). The saturation rate was calculated by correlating the temperature and salinity data using the UNESCO Table (1973).

For the analysis of dissolved inorganic nutrients, the water samples were stored in plastic bottles $(300 \mathrm{ml})$ and immediately frozen and transported to the Chemistry Laboratory of the Oceanography Department of UFPE. In the laboratory, analyses were performed as described by STRICKLAND and PARSONS (1972) and GRASSHOFF et al. (1983).

Samples for phytoplankton biomass analysis were taken on the surface and at DCM (80 to $100 \mathrm{~m})$ and $3 \mathrm{~L}$ of water were filtered for each depth. Membranous filters of cellulose acetate $47 \mathrm{~mm}$ in diameter with porosity of 0.45 $\mu \mathrm{m}$ (Schleicher and Schüll) were used. After drying, the filters were wrapped in aluminum foil, packed in paper envelopes properly identified and kept in the freezer at $-18{ }^{\circ} \mathrm{C}$ until their analysis. The method for determining the chlorophyll $a$ was the spectrophotometric analysis of UNESCO (1966).

In order to extract chlorophyll $a$, test tubes of $10 \mathrm{ml}$ were used, with $90 \%$ acetone, leaving them in a freezer at a temperature of $-18{ }^{\circ} \mathrm{C}$ for 24 hours in order to make it possible to extract these pigments. After this period, the material was centrifuged for 10 minutes at $3000 \mathrm{rpm}$ and the supernatant was placed in optical cuvettes of 1 $\mathrm{cm}^{3}$, and the respective absorbance readings were made on a spectrophotometer. To calculate the concentration of chlorophyll $a$, PARSONS and STRICKLAND (1963) equation was applied.

\section{DATA ANALYSIS}

For the significance test, the data were assessed for normality using the Shapiro-Wilk test, and normal data were tested by factorial ANOVA, in which the values of $p \leq 0.05$ were considered significant. A comparison was made between the environmental variables using the 


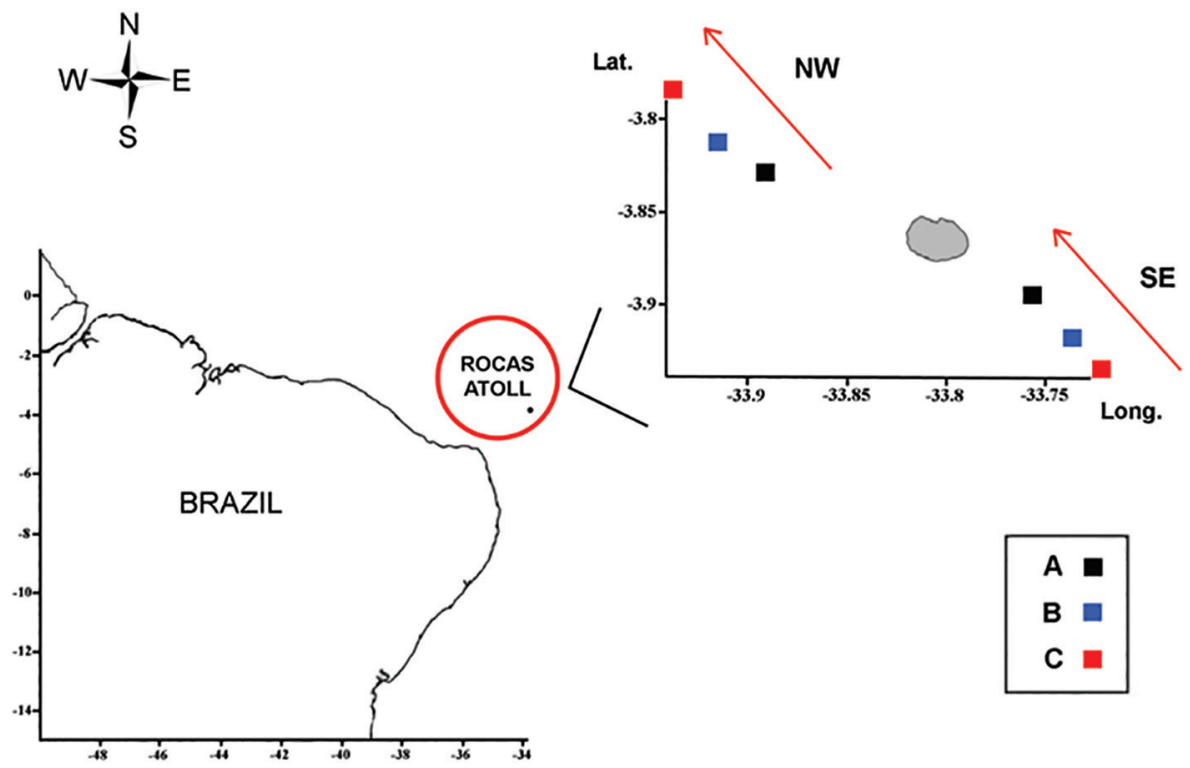

Figure 1. Map of the study area with sampling points and direction of the surface current, Southeast (SE) and Northwest (NW) in the Rocas Atoll (South Atlantic).

following factors: transects SE and NW; time, comparing the diurnal and nocturnal data, and depth, comparing the concentration of chlorophyll $a$ on the surface and at DCM. For these univariate analyses, the program STATISTICA 8.0 was used. For multivariate analysis, Principal Component Analysis (PCA) was performed, using the software Plymouth Routines in Multivariate Ecological Research (PRIMER 6).

\section{RESULTS}

The direction of the currents in this region during the campaign period were Southeasterly (SE) to Northwesterly (NW) (Figure 1). In these vertical profiles the deepening of the mixed layer was observed at the stations on the NW transect, with respect to the SE transect (Figure 2 to 4), where the region, with a depth between approximately 70 and $150 \mathrm{~m}$, appears more mixed due to the turbulence generated by the currents as they cross the Atoll.

For the rainfall analysis, the data from a meteorological station on Fernando de Noronha Archipelago were used. The ten-year mean value (from 2003 to 2012), for the month of July, was $170.05 \mathrm{~mm}$ of rainfall. However, in July 2010, an above average value of $396 \mathrm{~mm}$ of rainfall was observed.

Regarding the temperature, a significant difference could only be observed at the depth analyzed (Figure 5). On the SE transect, the mean temperature ranged from 26.23 to $27.84{ }^{\circ} \mathrm{C}$. On the NW transect, the temperature decreased significantly, exhibiting lower values at the depth of the DCM, reaching a mean value of $23.23^{\circ} \mathrm{C}$.

The salinity showed no significant difference in any of the factors analyzed. The means of the SE and NW transects were 36.1 and 36.2, respectively (Figure 6).

The dissolved oxygen showed significant differences in terms of depth. On both transects, the values of dissolved oxygen and its saturation rate were lower at the depth of DCM (Figure 7). On the NW transect lower values were more evident. The mean was $3.95 \mathrm{ml} . \mathrm{L}^{-1}$ with a saturation of $81.7 \%$ at the DCM, whereas on the SE transect, the mean was $4.47 \mathrm{ml} . \mathrm{L}^{-1}$ with a saturation of $92.8 \%$.

The research showed a significant difference in the DIN (dissolved inorganic nitrogen) in terms of depth as well as transect (Figure 8). The highest mean concentration was found on the NW transect and at the depth of DCM, with a mean of $4.26 \mu \mathrm{M}$. Although no significant difference in surface waters was observed, the mean content of DIN was also higher on the NW transect with the value of $0.84 \mu \mathrm{M}$, while on the SE transect, the mean value was $0.56 \mu \mathrm{M}$.

Only the depths showed significant differences in the concentration of DIP (dissolved inorganic phosphorus) (Figure 9). The contents of DIP were higher on both transects at the depth of DCM than at the surface. Mean values on the SE transect ranged from 0.16 to $0.18 \mu \mathrm{M}$ while the difference in mean values was more evident on the NW transect with 0.06 and $0.36 \mu \mathrm{M}$ at the surface and DCM, respectively. 

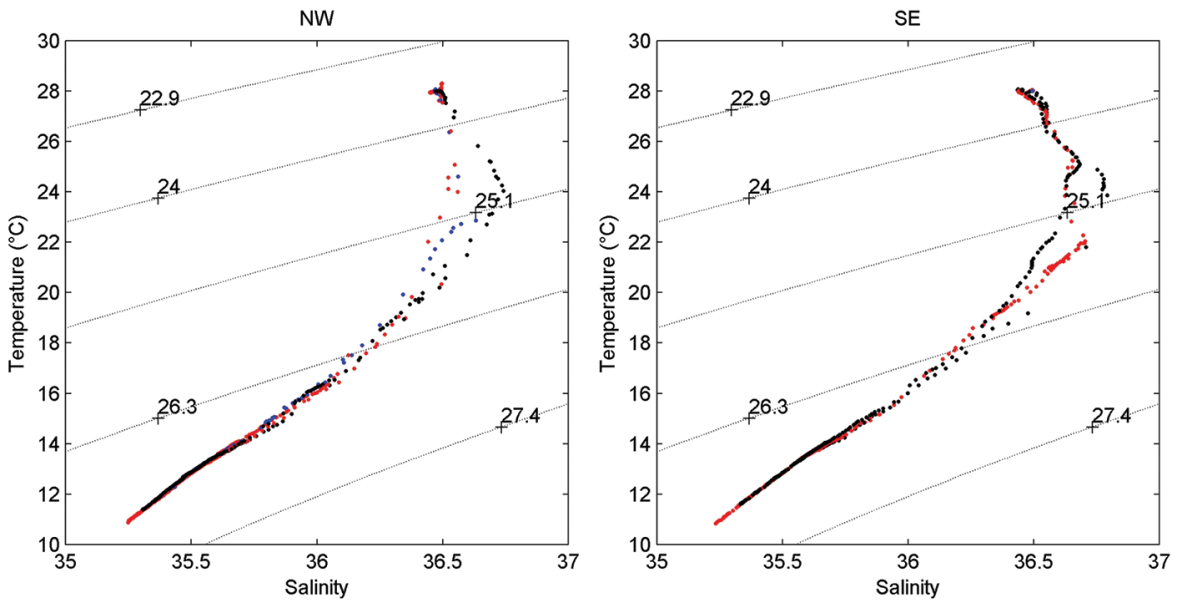

Figure 2. TS curve (Temperature-Salinity) around the Rocas Atoll (South Atlantic) in 2010.
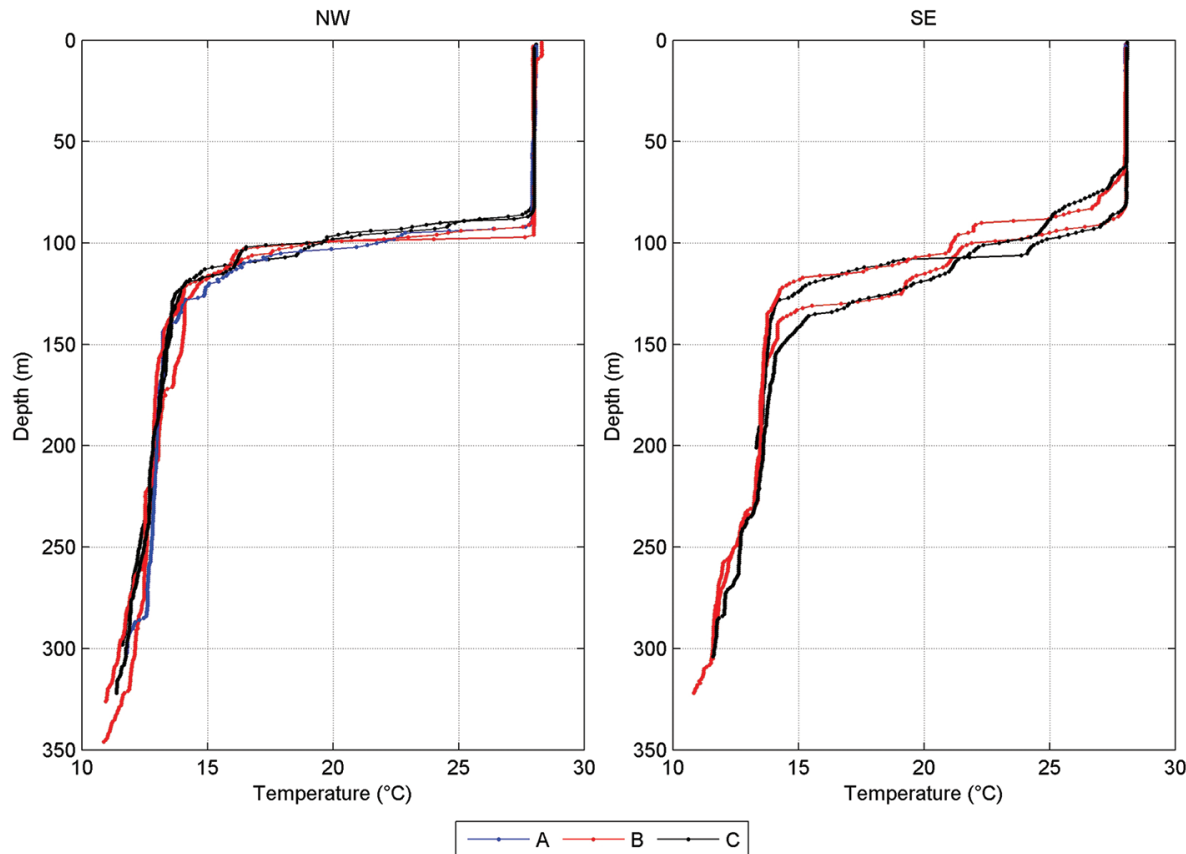

Figure 3. Vertical pattern of temperature $\left({ }^{\circ} \mathrm{C}\right)$ at points A, B and C around the Rocas Atoll (South Atlantic) in 2010.

The $\mathrm{SiO}_{2}$ (Silicate) content showed no significant difference between depths or transects (Figure 10). Besides the depth and transect factors, the difference in the concentration between the daytime and nighttime periods (time factor) was also analyzed. Regarding this factor, a significant difference was noted only in variable $\mathrm{SiO}_{2}$, with mean values of 1.62 and $1.02 \mu \mathrm{M}$ during the day and night, respectively (Figure 11).

The contents of chlorophyll $a$ showed no significant difference in any of the factors analyzed (Figure 12). However, mean values were highest at the depth of DCM, with values ranging from 0.79 to $0.87 \mathrm{mg} \cdot \mathrm{m}^{-3}$, on the NW and SE transects, respectively.

\section{PCA - Principal Component AnAlysis}

Based on the data a PCA was performed, by which it was found that three factors explained $86 \%$ of the variation in environmental variables, with the factor being represented by $58 \%, 15 \%$ and $13 \%$ respectively (Table 1 ).

Factor 1 showed a direct correlation between the variables dissolved oxygen and temperature, and an inverse correlation of these variables with the nutrients 


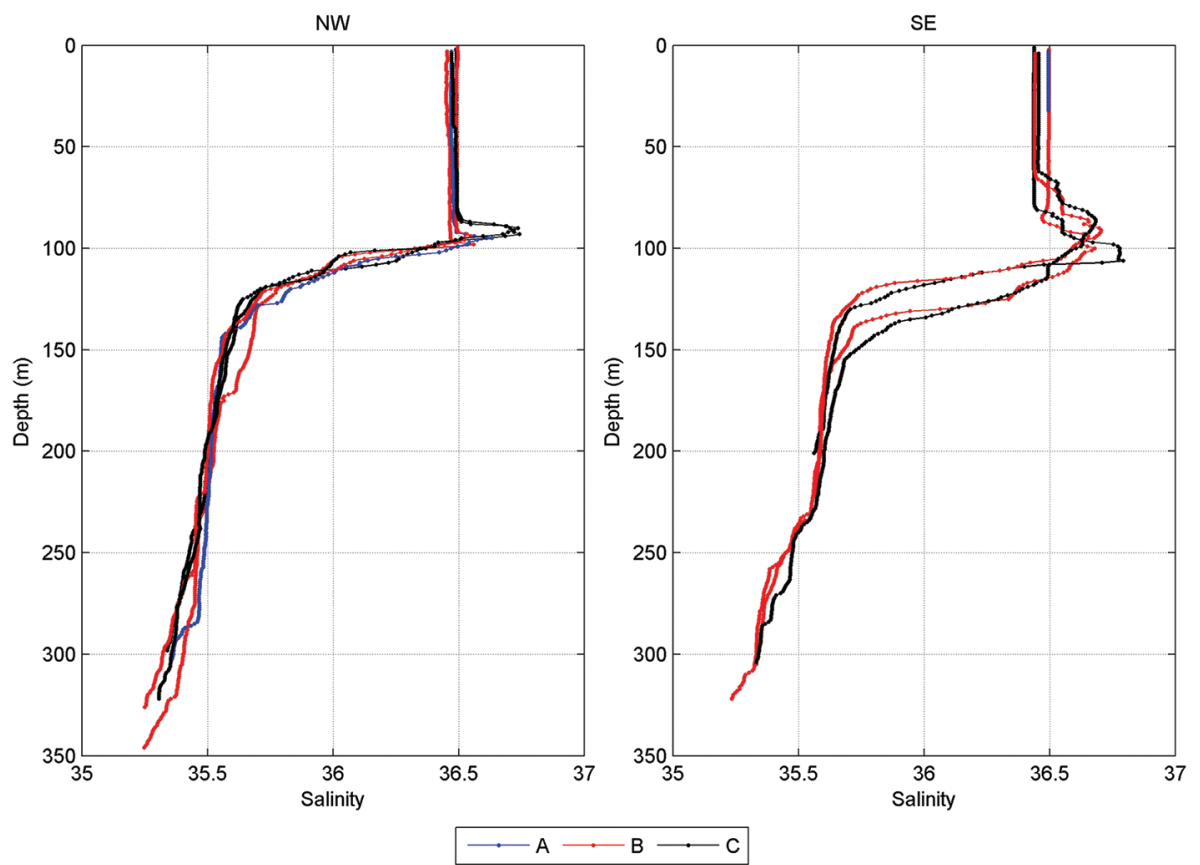

Figure 4. Vertical pattern of salinity at points A, B and C around the Rocas Atoll (South Atlantic) in 2010.

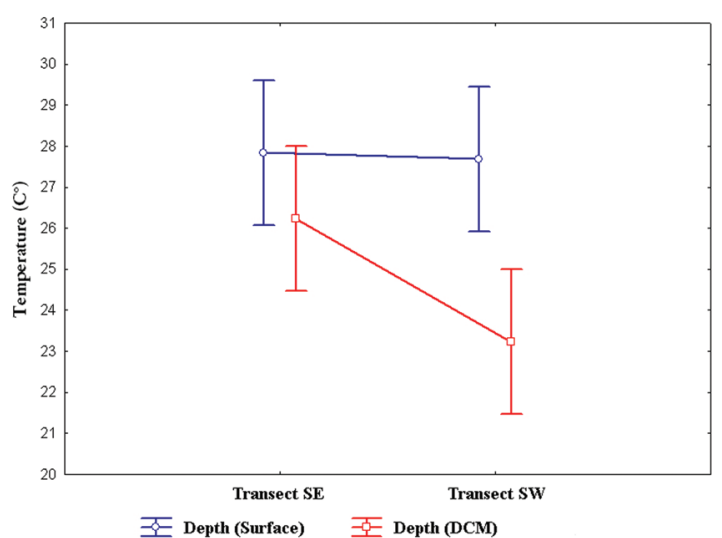

Figure 5. Spatial and vertical variation of temperature $\left({ }^{\circ} \mathrm{C}\right)$ around the Rocas Atoll (South Atlantic) in 2010.

DIP, DIN and $\mathrm{SiO}_{2}$. Factor 2 evidenced the salinity and factor 3, the chlorophyll $a$. However, the variables found in factors 2 and 3 were not correlated with any others (Figure 13).

\section{DISCUSSION}

The surface layer of the tropical Atlantic is dominated by the Tropical Surface Water (TSW) (STRAMMA; SCHOTT, 1999), with a low concentration of dissolved inorganic nutrients and low biological productivity, as is characteristic of the tropical oceans (SAMPAIO, 1998).

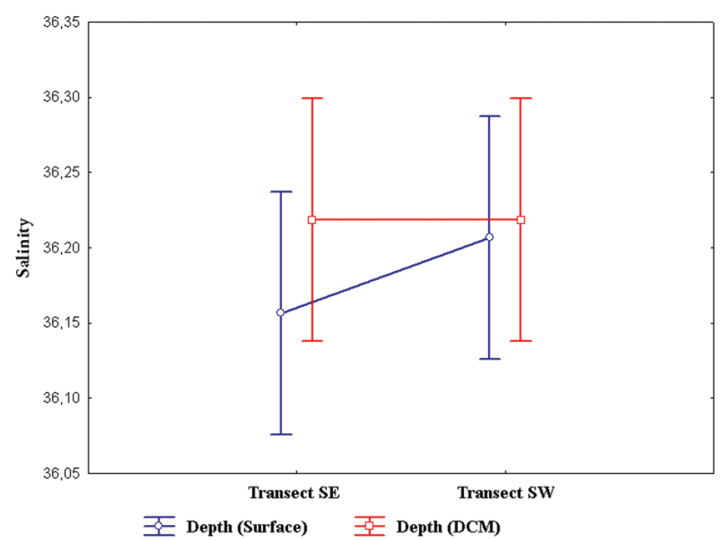

Figure 6. Spatial and vertical variation of salinity around the Rocas Atoll (South Atlantic) in 2010.

According to STRAMMA and SCHOTT (1999), the South Atlantic Central Water (SACW) is transported mainly within the South Equatorial Current (SEC) to the Brazilian Continental Shelf and is found below the TWS. Two types of SACW are found: the less dense type from the southwest subtropical South Atlantic that circulates in the subtropical gyre, and the denser type that probably originates in the southern South Atlantic.

Therefore, the oceanic current that most influences the study area is the SEC, and through the TS curve diagram (temperature and salinity) the direction of this current 


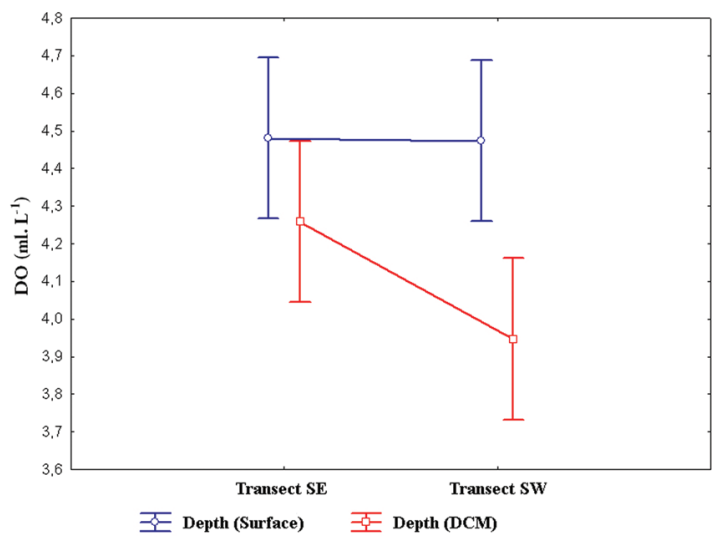

Figure 7. Spatial and vertical variation of dissolved oxygen (ml. $\left.\mathrm{L}^{-1}\right)$ around the Rocas Atoll (South Atlantic) in 2010.

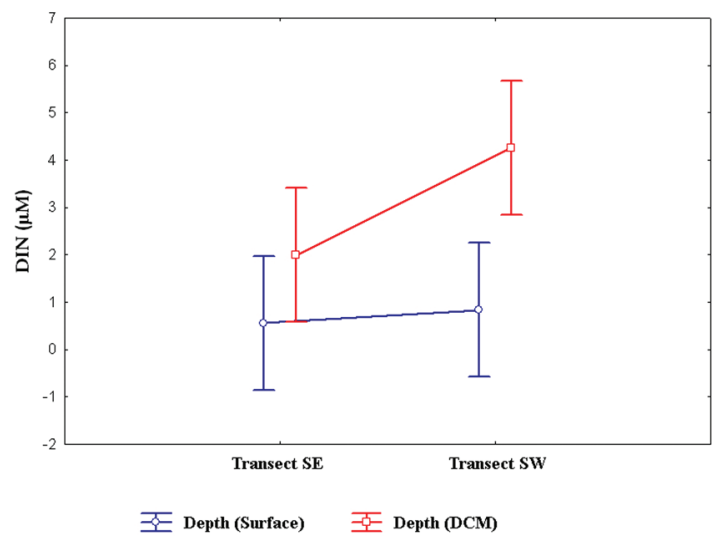

Figure 8. Spatial and vertical variation of DIN nitrite, nitrate and ammonia $(\mu \mathrm{M})$ around the Rocas Atoll (South Atlantic) in 2010.

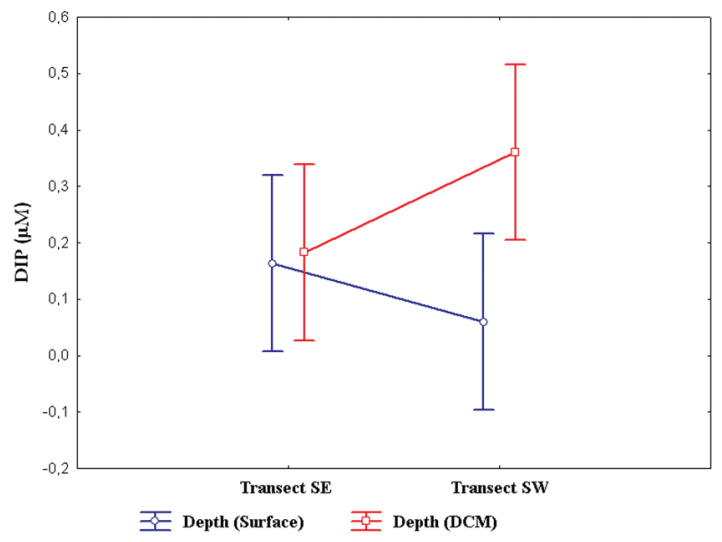

Figure 9. Spatial and vertical variation of DIP $(\mu \mathrm{M})$ around the Rocas Atoll (South Atlantic) in 2010.

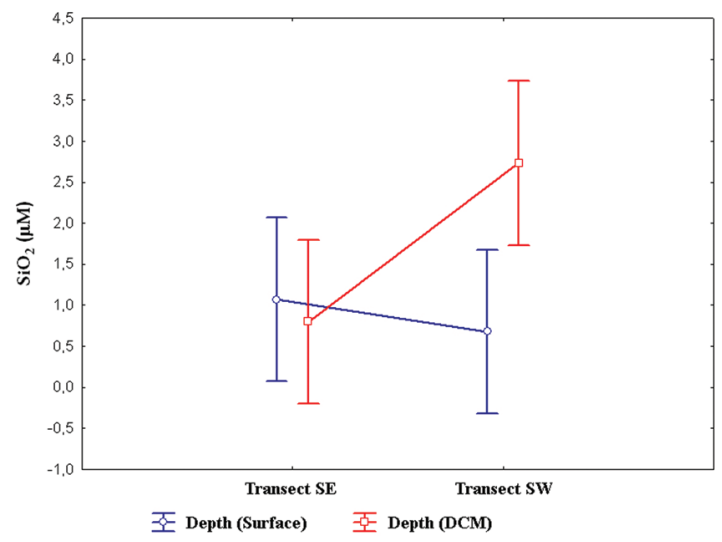

Figure 10. Spatial and vertical variation of silicate $(\mu \mathrm{M})$ around the Rocas Atoll (South Atlantic) in 2010.

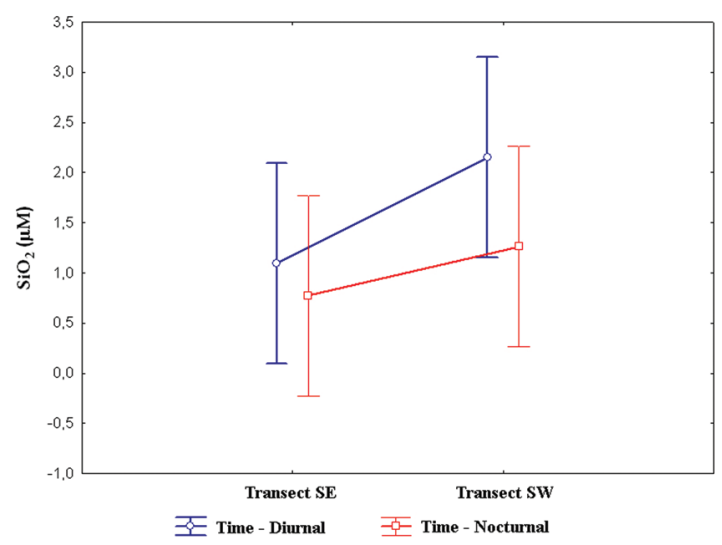

Figure 11. Temporal and vertical variation of silicate $(\mu \mathrm{M})$ around the Rocas Atoll (South Atlantic) in 2010.

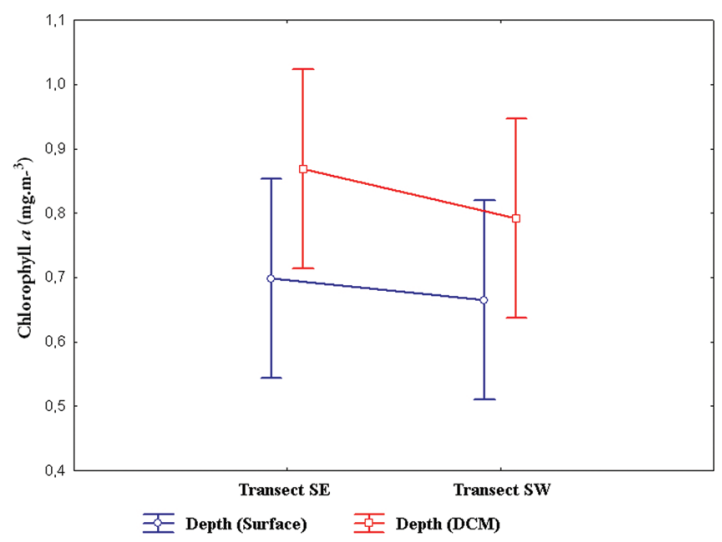

Figure 12. Spatial and vertical variation of chlorophyll $a$ (mg.m $\left.\mathrm{m}^{-3}\right)$ around the Rocas Atoll (South Atlantic) in 2010. 


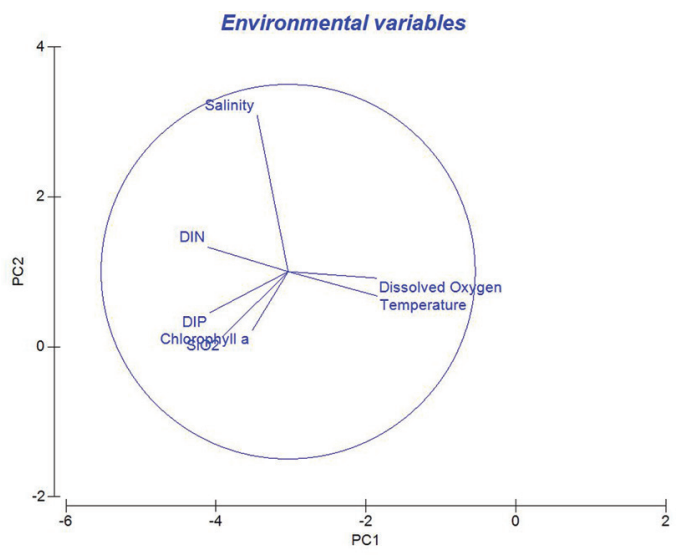

Figure 13. Principal Component Analysis of environmental variables around the Rocas Atoll (South Atlantic) in 2010.

Table 1. Principal Component Analysis around the Rocas Atoll (South Atlantic) in 2010.

\begin{tabular}{|c|c|c|c|}
\hline $\begin{array}{l}\text { ENVIRONMENTAL } \\
\text { VARIABLES }\end{array}$ & $\begin{array}{c}\text { Factor } 1 \\
(58 \%)\end{array}$ & $\begin{array}{c}\text { Factor } 2 \\
(15 \%)\end{array}$ & $\begin{array}{c}\text { Factor } 3 \\
(13 \%)\end{array}$ \\
\hline Dissolved Oxygen $\left(\mathrm{ml} \cdot \mathrm{L}^{-1}\right)$ & 0.472 & -0.035 & 0.160 \\
\hline Temperature $\left({ }^{\circ} \mathrm{C}\right)$ & 0.476 & -0.130 & 0.060 \\
\hline Salinity & -0.166 & 0.836 & 0.285 \\
\hline $\mathrm{DIN}(\mu \mathrm{M})$ & -0.432 & 0.131 & -0.145 \\
\hline $\mathrm{DIP}(\mu \mathrm{M})$ & -0.421 & -0.220 & 0.110 \\
\hline $\mathrm{SiO}_{2}(\mu \mathrm{M})$ & -0.351 & -0.347 & -0.272 \\
\hline Chlorophyll $a\left(\mathrm{mg} \cdot \mathrm{m}^{-3}\right)$ & -0.190 & -0.312 & 0.885 \\
\hline
\end{tabular}

which was bathing the Atoll (Southeast - SE) and other after the island (Northwest - NW), was determined.

In the Atoll a greater disruption of the thermohaline structure and the vertical displacement of isotherms on the NW transect were registered, and an increase in the depth of the variables temperature and salinity was observed. This was due to the process of turbulence generated after the passage through the Atoll, i.e., the factor known as "island mass effect".

In studies conducted by the Evaluation of the Sustainable Potential of Life's Resources in the Exclusive Economic Zone Program (REVIZEE), MEDEIROS et al. (2009) also observed differences in the thermohaline structure and the change in depth of isotherms, particularly close to the Seamounts of the North Chains and along the slope.

Despite the identification of mixture in the water mass, there was no evidence of a cold spot in the surface waters surrounding the atoll, the temperature was always over $26^{\circ} \mathrm{C}$. This indicates the improbability of the occurrence of the upwelling of deeper waters, rich in nutrients. In a study conducted by SOUZA et al. (2013), a similar result was observed in the Fernando de Noronha Archipelago and in the Seamounts of the North Chains. However, in the same study, the São Pedro e São Paulo Archipelago presented colder waters on the surface, which probably caused an enrichment of surface waters. Only the depths of the DCM, that range from 83 to $100 \mathrm{~m}$, presented temperatures below $20{ }^{\circ} \mathrm{C}$, thus showing that they are very close to the barrier between the TSW and SACW water masses.

Surface temperatures are similar to those reported by MEDEIROS et al. (1999) and SOUZA et al. (2013) in the Tropical Atlantic and FEITOSA and PASSAVANTE (2004) in the Rocas Atoll, but slightly below the values found by PINTO et al. (1997), who found a thermal variation from 28.00 to $32.20{ }^{\circ} \mathrm{C}$. The same happened with salinity, for which PINTO et al. (1997) found values between 35 and 39 whereas in the present study the salinity remained above 36 but did not exceed 36.43 .

Temperature is however, according to the results of PCA, directly correlated with the concentration of dissolved oxygen. In the surface layer, a greater dissolution of oxygen can be observed due to the influence of wind and thus it presents a similar pattern to most of the ocean. The same happens with the saturation rate, with lower values at the DCM.

Despite the fact that generally the decrease in temperature causes an increase in the dissolving capacity of gases, this study showed a decrease in the rate of dissolved oxygen below the surface layer. This fact can be explained by the consumption of dissolved oxygen by the biological activity of organisms and the oxidization of organic matter. Similar patterns occurred in the study performed in the JOPS (Joint Oceanographic Projects) by MEDEIROS et al. (1999).

All nutrients showed significant differences in some of the factors analyzed and were higher at the DCM, a fact also observed by SOUZA et al. (2013) in the Tropical Atlantic.

However, the contents of the DIN presented the greatest differentiation, as they showed not only differences as between depths but also between the transects, thus emphasizing the disturbance of the thermohaline structure and the vertical displacement of isotherms on the NW transect, as quoted above. On the other hand, the DIP showed no differentiation between transects, but like most other parameters, it presented differences between depths.

Both DIN and DIP attained a higher concentration in the Rocas Atoll, reaching a maximum of 5.72 and 0.61 $\mu \mathrm{M}$, respectively, when compared with the Tikehau Atoll, 
Tuamotu Archipelago, French Polynesia (CHARPY; CHARPY-ROUBAUD, 1990) and the Tyrrhenian Sea in the Mediterranean (MISIC et al., 2012). In the Tikehau Atoll, the authors observed maximum values of 0.09 and $0.016 \mu \mathrm{M}$ and in the Tyrrhenian Sea, values of 4.40 and $0.20 \mu \mathrm{M}$ for nitrogen and phosphorus, respectively.

In a study conducted in the waters of Northeastern Brazil by MEDEIROS et al. (1999), the distribution pattern of nutrients was similar, though the lower concentrations in the surface layer increased with depth. However, the values were higher, reaching concentrations greater than 10 and $1 \mu \mathrm{M}$ for nitrogen and phosphorus, respectively.

In the Rocas Atoll, the maximum value of silicate was $5.49 \mu \mathrm{M}$, being slightly higher than that in the Tyrrhenian Sea in the Mediterranean, which showed a maximum value of $4.18 \mu \mathrm{M}$ (MISIC et al., 2012). In other studies conducted in the Rocas Atoll, the maximum values of silicate found were 16.51 and $17.52 \mu \mathrm{M}$, by, respectively, FEITOSA and PASSAVANTE (2004) and SOUZA et al. (2013). The silicate was the only parameter that showed a significant difference between the time periods, with the lowest values occurring during the night. This fact is probably due to the consumption of silicate by the nanoplankton. As observed by KOCHHANN (2011), zooplanktonic radiolarians have broad spatial and temporal distribution in the ocean basins. The skeleton of radiolarians is impregnated with silicate and their vertical distribution in the water column of the Central Pacific is at a maximum in the layer between 70-110 $\mathrm{m}$ depth.

According to the results of the PCA, the DIN, DIP and silicate showed inverse correlations to temperature. This can be explained by the fact that the samplings were performed in the DCM, which coincided with the meeting of the water masses.

In oceanic areas, the processes that occur in the first hundred meters are essential for the heat exchanges with the atmosphere and for organic production. In this layer, the search for light and nutrients is undertaken simultaneously by the producers.

According to MARGALEF (1978), the characteristics of planktonic organisms that do not change easily, as far as the morphological, mechanical and general physiological properties of the cells are concerned, are less sensitive to temperature, salinity and shades of light, and much more dependent on turbulence and general nutrient availability. However, according to GOLDMAN (1988), turbulence and other small scale physical processes may be limiting a wide range of biological processes such as the absorption of nutrients by the phytoplankton.

One of the best known phytoplankton features is the maximum subsurface chlorophyll $a$, which develops during periods of stratification in different regions of the ocean (GIANESELLA, 2000).

According to LALLI and PARSON (2006), regions with low concentrations of essential nutrients, and therefore, low primary productivity, are called oligotrophic. These areas typically have chlorophyll $a$ concentrations lower than $0.05 \mathrm{mg} \cdot \mathrm{m}^{-3}$ at the surface and a maximum of 0.10 to 0.50 mg. $\mathrm{m}^{-3}$ at a depth of 100 to $150 \mathrm{~m}$. Eutrophic waters contain high concentrations of nutrients and high phytoplankton densities that are expressed by chlorophyll concentrations from 1.0 to $10 \mathrm{mg} \cdot \mathrm{m}^{-3}$ in the surface layer. Mesotrophic is a term sometimes applied to intermediate waters with concentrations ranging from 0.60 to $0.90 \mathrm{mg} \cdot \mathrm{m}^{-3}$.

However, chlorophyll a concentrations and macronutrients cannot be the only factors to define oligotrophic or eutrophic areas. Over $20 \%$ of the world's open-ocean surface waters are characterized by the presence of adequate nitrate, phosphate and silicate in the euphotic zone, but have a relatively low corresponding phytoplankton biomass. Thus, biological productivity is often limited by a lack of micronutrients such as iron (MARTIN et al., 1994).

The DCM are common in situations of oligotrophy, such as those found in the large gyre of the Atlantic and Pacific oceans and in temperate areas during the summer. The upper layers of the photic zone have nutritional depletion and a subsurface maximum of chlorophyll $a$ occurs within the pycnocline associated with the nutricline (GIANESELLA, 2000).

The chlorophyll $a$ around the Rocas Atoll showed low concentrations, with values ranging from 0.30 to 1.07 mg. $\mathrm{m}^{-3}$, the same pattern occurring in studies conducted in oceanic regions by FEITOSA and PASSAVANTE (2004), MISIC et al. (2012) and SOUZA et al. (2013), with values from 0.64 to $1.10 \mathrm{mg} \cdot \mathrm{m}^{-3}, 0.01$ to $0.93 \mathrm{mg} \cdot \mathrm{m}^{-3}$ and 0.46 to $1.65 \mathrm{mg} \cdot \mathrm{m}^{-3}$, respectively.

In Southeastern Brazil, GIANESELLA (2000) states that the greater variability between the depth of maximum chlorophyll $a$ and nitracline was mainly due to the high nitrate concentrations observed at the surface without a corresponding increase in phytoplankton biomass. Turbulent processes in the mixed layer or the unavailability of any micronutrient due to the presence of 
chelating agents in water were the hypotheses offered to explain this low biomass.

Regarding the water surrounding the Atoll, there was a relative increase in the chlorophyll $a$ content in the mixed layer due to the influence of a nutrient rich water mass, the SACW. Most of the environmental variables analyzed showed a significant increase due to turbulence. Therefore, the content of chlorophyll $a$, in spite of presenting an increase, was not significant. This could possibly be due to the negative effect of turbulence, as explained by GOLDMAN (1988), or to the lack of any micronutrient corroborating with GIANESELLA (2000).

The present study indicates that low concentrations of chlorophyll $a$ in the study region show that the productivity of phytoplankton is low and that the most plentiful food supply for the next link in the trophic web (zooplankton) is provided by the productivity of phytobenthos, mucus and aggregate organic matter produced by the benthic community of the Atoll, just as in the study undertaken by NOGUEIRA and SASSI (2011). According to MITRA et al. (2014), the microbial loop surely makes its contribution due the existence of protist mixotrophs. However, the realisation that these organisms are major players in the planktonic food web, contributing substantially to the flow of carbon and other nutrients in aquatic ecosystems, is new and requires more research for the adequate simulation of these events.

Despite the increase observed in some variables such as nutrient salts and chlorophyll $a$, the temperature in the mixed layer reached a mean value of $23.23{ }^{\circ} \mathrm{C}$ due to the predominance of Tropical Water. The increase of phytoplankton biomass on the NW transect was, therefore, caused by the "island effect" and not by upwelling.

\section{ACKNOWLEDGEMENTS}

The authors wish to express their thanks to the Ministry of Science and Technology (MCT), the Chico Mendes Institute for Biodiversity Conservation (ICMBio), the Directorate of Hydrography and Navigation (of the Brazilian Navy), the Federal University of Pernambuco and the Fund for the Support of Science and Technology of Pernambuco (FACEPE), for their logistical support and the undertaking of the research collections.

\section{REFERENCES}

CHARPY, L.; CHARPY-ROUBAUD, C. J. A model of the relationship between light and primary production in an Atoll lagoon. J. Mar. Biol. Ass. U. K., v. 70, p. 357-369, 1990.
CHAVES, T. B. C.; MAFALDA JR, P. O.; SANTOS, C.; SOUZA, C. S.; MOURA, G.; SAMPAIO, J.; MELO, G. Biomassa planctônica e hidrografia na Zona Econômica Exclusiva do Nordeste do Brasil. Trop. Oceanogr., v. 36, p. 14-27, 2008.

CORDEIRO, T. A.; BRANDINI, F. P.; ROSA, R. S.; SASSI, R. Deep Chlorophyll Maximum in Western Equatorial Atlantic - How does it Interact with Islands Slopes and Seamounts? Mar. Sci., v. 3, n. 1, p. 30-37, 2013.

DOTY, M. S.; OGURI, M. The island mass effect. J. Cons. Int. Explor. Mer., v. 22, n. 1, p. 33-37, 1956.

FEITOSA, F. A. N.; PASSAVANTE, J. Z. O. Produtividade fitoplanctônica e hidrologia do Atol das Rocas (Brasil). In: CHELLAPPA, N. T.; CHELLAPA, S.; PASSAVANTE, J. Z. O. (Eds.). Ecologia aquática tropical. Natal: ServGraf, 2004. p. $143-156$.

GHERARDI, D. F. M.; BOSENCE, D. W. J. Composition and community structure of the coralline algal reefs from Atol das Rocas, South Atlantic, Brazil. Coral Reefs, v. 19, n. 3, p. 205219, 2001 .

GHERARDI, D. F. M.; BOSENCE, D. W. J. Modeling of the ecological succession of encrusting organisms in recent coralline-algal frameworks from Atol das Rocas, Brazil. Palaios, v. 4, p. 145-158, 1999

GHERARDI, D. F. M.; BOSENCE, D. W. J. Late Holocene Reef growth and relative sea-level changes in Atol das Rocas, equatorial South Atlantic. Coral Reefs, v. 24, n. 2, p. 264$272,2005$.

GIANESELLA, S. M. F. Variabilidade da camada de clorofila máxima na região de quebra da Plataforma Continental Sudeste Brasileira. 2000. 166f. Tese (Livre-Docência) - Instituto Oceanográfico, Universidade de São Paulo, São Paulo, 2000. http://www.teses.usp.br/teses/disponiveis/livredocencia/21/ tde-04052010-103957/pt-br.php

GIANESELLA, S. M. F.; SALDANHA-CORRÊA, F. M. P. Sustentabilidade dos oceanos. São Paulo: Blucher press, 2010. 200 p.

GILMARTIN, M.; REVELANTE, N. The "island mass" effect on the phytoplankton and primary production of the Hawaiian islands. J. Exp. Mar. Biol. Ecol., v. 16, p.181-204, 1974.

GOLDMAN, J. C. Spatial and temporal discontinuities of biological process in pelagic surface waters. In: ROSTHCHILD, B. (Ed.). Toward a Theory of Biological and Physical Interaction in the world ocean. Amsterdam: Kluwer, 1988, p. 273-296.

GRASSHOFF, K.; EHRHARDT, M.; KREMLING, K. Methods of seawater analysis. 3rd ed. Weinheim: Verlag Chemie, $1983.419 \mathrm{p}$

HOPPENRATH, M; ELBRÄCHTER, M.; DREBES, G. Marine phytoplankton: Selected microphytoplankton species from the North Sea around Helgoland and Sylt. 1st ed. Stuttgart: Schweizerbart Science Publishers press, 2009. 264 p.

KIKUCHI, R. K. P.; LEÃO, Z. M. A. N. Rocas (Southwestern Equatorial Atlantic, Brazil): an atoll built primarily by coralline algae. In: 8th INTERNATIONAL CORAL REEF SYMPOSIUM, 1997, Panamá. Proceedings. International Society for Reef Studies. Panamá, 1997. p. 731-736.

KOCHHANN, K. G. D. Radiolários: estado do conhecimento e aplicações às geociências. Terra. Didat., v. 7, n. 1, p. 18-28, 2011.

LALLI, C. M.; PARSON, T. R. Biological Oceanography: an introduction. 2nd ed. Amsterdam: Elsevier, 2006. 314 p. 
LEITE, T. S.; HAIMOVICI, M.; LINS, J. E. A pesca de polvos no Arquipélago de Fernando de Noronha, Brasil. Bol. Inst. Pesca, v. 34, n. 2, p. 271-280, 2008.

LIRA, S. M. A.; TEIXEIRA, I. A; LIMA, C. D. M; SANTOS, G. S.; LEITÃO, S. N.; SCHWAMBORN, R. Spatial and nycthemeral distribution of the zooneuston of Fernando de Noronha, Brazil. Braz. J. Oceanogr., v. 62, n. 1, p. 35-45, 2014.

LONGHURST, A. R.; PAULY, D. Ecologia de oceanos tropicais. 2nd ed. São Paulo: EDUSP, 2007. 419 p.

MACÊDO, S. J.; MONTES, M. J. F.; COSTA, K. M. P. Oceanografia Biológica: Condições hidrológicas da Zona Econômica Exclusiva (ZEE) do Nordeste. In: FÁBIO, V. H. H. (Org.). Programa REVIZEE - Score Nordeste. Fortaleza: Martins \& Cordeiro, 2009. p. 104-136.

MAFALDA JÚNIOR, P. O.; MOURA, G.; MELO, G.; SAMPAIO, J.; FEITOSA, F. A. N.; PASSAVANTE, J. Z. O.; SOUZA, M.O.; SAMPAIO, C. Oceanografia Biológica: Biomassa Fitoplanctônica na ZEE da Região Nordeste do Brasil. In: FÁBIO, V. H. H. (Org.). Programa REVIZEE Score Nordeste. Fortaleza: Martins \& Cordeiro, 2009. p. 1123.

MARGALEF, R. Life-forms of phytoplankton as survival alternatives in an unstable environment. Oceanol. Acta, v. 1, n. 4, p. 493-509, 1978.

MARTIN, J. H.; COALE, K. H.; JOHNSON, K. S.; FITZWATER, S. E.; GORDON, R. M.; TANNER, S. J.; HUNTER, C. N.; ELROD, V. A.; NOWICKI, J. L.; COLEY, T. L.; BARBER, R. T.; LINDLEY, S.; WATSON, A. J.; VAN SCOY, K.; LAW, C. S.; LIDDICOAT, M. I.; LING, R.; STANTON, T.; STOCKEL, J.; COLLINS, C.; ANDERSON, A.; BIDIGARE, R.; ONDRUSEK, M.; LATASA, M.; MILLERO, F. J.; LEE, K.; YAO, W.; ZHANG, J. Z.; FRIEDERICH, G.; SAKAMOTO, C.; CHAVEZ, F.; BUCK, K.; KOLBER, Z.; GREENE, R.; FALKOWSKI, P.; CHISHOLM, S. W.; HOGE, F.; SWIFT, R.; YUNGEL, J.; TURNER, S.; NIGHTINGALE, P.; HATTON, A.; LISS, P.; TINDALE, N. W. Testing the iron hypothesis in ecosystems of the equatorial Pacific Ocean. Nature, v. 371, p. 123-129, 1994.

MARTINEZ, E.; MAAMAATUAIAHUTAPU, K. Island mass effect in the Marquesas Islands: Time variation. Geophys. Res. Lett., v. 31, p. 1-4, 2004.

MEDEIROS, C.; ARAÚJO, M.; FREITAS, I.; ROLLNIC, M. Massas d'água da região oeste do Atlântico tropical. In: HAZIN, F. H. V. (Org.). Meteorologia e Sensoriamento Remoto, Oceanografia Física, Oceanografia Química e Oceanografia Geológica. Programa REVIZEE - Score Nordeste. Fortaleza: Martins \& Cordeiro, 2009. p. 56-69.

MEDEIROS, C.; MACÊDO, S. J.; FEITOSA, F. A. N.; KOENING, M. L. Hydrography and phytoplankton biomass and abundance of North-East Brazilian waters. Arch. Fish. Mar. Res., v. 47, n. 2/3, p. 133-151, 1999.

MELO, P. A. M. C.; DIAZ, X. F. G.; MACEDO, S. J.; NEUMANN-LEITÃO, S. Diurnal and spatial variation of the mesozooplankton community in the Saint Peter and Saint Paul Archipelago, Equatorial Atlantic. Mar. Biodivers. Rec., v. 5, p. 1-14, 2012.
METZLER, P. M.; GLIBERT, P. M.; GAETA, S. A.; LUBLAN, J. New and regenerated production in the South Atlantic of Brazil. Deep-Sea Res., v. 44, n. 3, p. 363-384, 1997.

MISIC, C.; BAVESTRELlO, G.; BO, M.; BORGHINI, M.; CASTELLANO, M.; HARRIAGUE, A. C.; MASSA, F.; SPOTORNO, F.; POVERO, P. The "seamount effect" as revealed by organic matter dynamics around a shallow seamount in the Tyrrhenian Sea (Vercelli Seamount, western Mediterranean). Deep-Sea Res., v. 67, p. 1-11, 2012.

MITRA, A.; FLYNN, K. J.; BURKHOLDER, J. M.; BERGE, T.; CALBET, A.; RAVEN, J. A.; GRANÉLI, E.; GLIBERT, P. M.; HANSEN, P. J.; STOECKER, D. K.; THINGSTAD, F.; TILLMANN, U.; VAGE, S.; WILKEN, S.; ZUBKOV, M. $\mathrm{V}$. The role of mixotrophic protists in the biological carbon pump. Biogeosciences, v. 11, p. 995-1005, 2014.

MORAES, F. C.; VILANONA, E. P.; MURICY, G. Distribuição das esponjas (Porifera) na reserva biológica do Atol das Rocas, Nordeste do Brasil. Arq. Mus. Nac. (Rio de J.), v. 61, n. 1, p. 13-22, 2003.

PALACIOS, D. M. Factors influencing the island-mass effect of the Galapagos archipelago. Geophys. Res. Lett., v. 29, n. 23, p. 21-34, 2002.

PARSONS, T. R.; STRICKLAND, J. D. H. Discussion of spectrophotometric determination of marine plankton pigments, with revised equations of ascertaining chlorophyll a and carotenoids. J. Mar. Res., v. 21, n. 3, p. 155-163, 1963.

PINTO, N. C. T.; MAFALDA, P.; SANTOS, A. T. Caracterização do zooplâncton da Reserva Biológica do Atol das Rocas na Campanha de março-1991(verão). Trab. Oceanog. Univ. Fed. PE, v. 25, p. 31-46, 1997.

SAMPAIO, J. A. A. Distribuição horizontal e vertical da clorofila a fitoplanctônica em águas da Zona Econômica Exclusiva do Nordeste Brasileiro. João Pessoa: Relatório Técnico Final, 1998. $21 \mathrm{p}$

NOGUEIRA, E. M. S.; SASSI, R. Nychthemeral variations of tintinnina (Ciliata: Oligotrichida) near the Rocas Atoll (South Atlantic) and relationship with other microzooplanktonic components. Arq. Ciênc. Mar., v. 44, n. 1, p. 5-11, 2011.

SCHULZ-NETO, A. Aves marinhas do Atol das Rocas. In: Branco, J. O. (Ed.) Aves marinhas e insulares brasileiras: bioecologia e conservação. Itajaí: UNIVALI, 2004, p. 169-192.

SOUZA, C. S.; LUZ, J. A. G.; MACÊDO, S. J.; MONTES, M. J. F.; MAFALDA, P. Chlorophyll a and nutrient distribution around seamounts and island of the tropical south-western Atlantic. Mar. Fish. Rev., v. 64, p. 168-184, 2013.

STRAMMA, L.; SCHOTT, F. The mean flow field of the tropical Atlantic Ocean. Deep-Sea Res. II, v. 46, p. 279-303, 1999.

STRICKLAND, J. D. H.; PARSONS, T. R. A practical handbook of sea water analysis. Bull. Fish. Res., v.167, p. 1-311, 1972.

UNESCO. International Oceanographic Table. 2nd ed. Wormly: National Institute of Oceanography of Great Britain \& UNESCO, 1973.

UNESCO. Determination of photosynthetic pigments in sea water. Paris: Monography on Oceanography Methodology, 1966. $69 \mathrm{p}$ 